\title{
MANAJEMEN HARTA DALAM ISLAM DARI PERSPEKTIF HADITS
}

\section{ISLAMIC ASSET MANAGEMENT FROM HADITS PERSPECTIVE}

\author{
Basrowi'ia, M. Zaki² \\ 1aSekolah Tinggi Ekonomi Bisnis Islam (STEBI) Lampung, Indonesia, e-mail: \\ m.busro25@yahoo.com \\ ${ }^{2}$ Dosen Magister Ekonomi Syariah PPs UIN Radin Intan Lampung
}

\begin{abstract}
The purpose of this study is to describe property management in Islam from a hadith perspective. Writing method, namely by using literature studies by examining various scientific literature ranging from "kitab", books, journals, Islamic magazines, and various digital sources. This paper has been given a limited seminar with students participating in the post-graduate program of Islamic economics, 2018 Radin Intan State Islamic University on October 5,2018 , and has been corrected based on input from the participants. Based on the results of the discussion, it can be concluded that: 1) property in Islam is absolute, Allah's righteousness, and humans are only entrusted; 2) The position of property in Islam has a very important role, therefore it must be managed (management) so that it can be used as a means to worship, 3) in the acquisition of assets must be obtained by lawful means and utilized in a halal way too, 4) everyone must able to become a treasure that he has well, 5) in its utilization it cannot be wasteful, 6) the treasure is a test, and 7) woe to those who worship treasure.
\end{abstract}

Keywords: Property, Hadith, Management

\begin{abstract}
ABSTRAK
Tujuan kajian ini adalah untuk mendeskripsikan manajemen harta dalam islam dari perspektif hadits. Metode penulisan, yaitu dengan menggunakan studi literatur dengan mengkaji berbagai literature ilmiah mulai dari kitab, buku, jurnal, majalah Islam, dan berbagai sumber digital. Makalah ini telah diseminarkan secara terbatas di hadapan mahasiswa program pascasana magister ekonomi syariah, Universitas Islam Negeri Radin Intan angkatan 2018 pada tanggal 5 Oktober 2018, dan telah diperbaiki berdasarkan masukan dari para peserta. Berdasarkan hasil pembahasan dapat disimpulkan, bahwa: 1) harta dalam Islam adalah mutlak mulik Alloh, dan manusia hanya bersifat mendapatkan titipan; 2) Kedudukan harta dalam Islam mempunyai peran sangat penting, oleh karena itu harus dikelola (manajemen) agar dapat dijadikan sebagai sarana untuk beribadah, 3) dalam perolehan harta harus diperoleh dengan cara halal dan dimanfaatkan dalam jalan yang halal pula, 4) setiap orang harus mampu menjadi harta yang ia miliki dengan baik, 5) dalam pemanfaatannya tidak boleh boros dan dihambur-hamburkan, 6) Harta itu adalah ujian, dan 7) celakalah bagi orang yang menyembah harta.
\end{abstract}

Kata Kunci: Harta, Hadits, Manajemen

Basrowi. 2020. Manajemen Harta Dalam Islam Dari Perspektif Hadits. Jurnal Syarikah 6 (2): $160-170$. 


\section{PENDAHULUAN}

\begin{tabular}{|c|c|}
\hline Dalam & realitas \\
\hline $\begin{array}{l}\text { kepemilikan } \\
\text { standarisasi }\end{array}$ & $\begin{array}{l}\text { realitas } \\
\text { atas harta } \\
\text { dalam }\end{array}$ \\
\hline
\end{tabular}
kebahagiaan hidup seseorang, harta yang melimpah menunjukkan bahwa ia adalah orang yang berbahagia. Dengan asumsi tersebut, manusia cendrung berlombalomba untuk memperbanyak harta kekayaan yang dimiliki, karena kebutuhan manusia atau kesenangan manusia terhadap harta sama posisinya dengan kebutuhan hidup manusia terhadap anak dan atau keturunan. Sehingga dengan demikian kebutuhan manusia terhadap harta merupakan kebutuhan yang mendasar.

Harta merupakan karunia Allah SWT untuk umat manusia, ia bagaikan perhiasan yang bisa menambah indahnya kehidupan di dunia, ia merupkan suatu hal yang selalu dipikirkan oleh manusia, bahkan banyak orang yang mengorbankan tenaga dan fikirannya untuk memperoleh harta sebanyak-banyaknya. Banyak manusia beranggapan bahwa orang sukses adalah orang yang mampu mengumpulkan pundipundi harta sebanyak-banyaknya, orang belum disebut sukses jika belum mempunyai banyak harta. Agaknya penyakit materialis inilah yang terjadi pada zaman sekarang, manusia mempunyai standar kesuksesan diukur dari banyaknya harta yang dimiliki.

Sebenarnya Islam mengakui bahwa eksistensi harta sangat penting untuk mendukung penyempurnaan pelaksanaan ibadah baik yang ritual ataupun sosial, bahkan jihad salah satunya harus dengan harta. Oleh sebab itu, Islam melalui alQur'ān dan Hadīs memberikan tuntunan mengenai harta, agar manusia bisa memposisikan harta dengan benar untuk meraih keselamatan dan kebahagiaan di dunia dan akhirat sebagaimana tujuan aktifitas ekonomi Islam.

Islam memandang keinginan manusia untuk memperoleh, memiliki, dan memanfaatkan harta sebagai sesuatu yang lazim. Harta diperoleh, dimiliki, dan dimanfaatkan manusia untuk memenuhi hajat hidupnya, baik bersifat materi maupun non materi. Namun, semua motivasi ini dibatasi dengan aturan-aturan Allah yang harus diperhatikan oleh manusia agar dalam proses baik pencarian, pemilikan dan pemanfaatan harta tersebut tidak menimbulkan kekacauan dalam kehidupan. Namun sebaliknya, kondisi pada saat ini, motivasi untuk memperoleh harta tersebut banyak keluar dari aturanaturan yang telah ditetapkan, sehingga baik dalam proses pencarian, kepemilikan maupun pemanfaatannya ada pihak-pihak yang terdholimi dan menjadikan pelaksanaan Islam sebagai way of life yang diharapkan melahirkan tatanan hayatan thayyibah tidak bisa terwujud dengan sepenuhnya.

Membaca uraian di atas dapat dipahami bahwa dalam Islam pemilik harta secara mutlak adalah Allah SWT, yang diberikan kepada hamba-Nya sebagai amanah yang harus dipegang dengan baik, sebagai perhiasan yang menambah kebahagiaan dalam hidup, sebagai ujian keimanan, dan sebagai bekal ibadah.

Berangkat dari permasalahan di atas, maka tulisan singkat ini diharapkan bisa membuka lebar-lebar pikiran kita bagaimana sebenarnya konsep harta dalam perspektif Hadits dari perspektif hadits? Sehingga dalam pencarian, kepemilikan dan pemanfaatan harta kita tidak melanggar aturan-aturan yang ditetapkan pemilik harta yang haqiqi yaitu Allah SWT.

\section{MATERI DAN METODE}

Penelitian ini masuk dalam kategori penelitian kualitatif dengan perspektif literatur atau kepustakaan. Penelitian dilakukan pada bulan September s.d. Desember 2018. Data skunder digali dari berbagai literatur relevan, terutama yang sudah on-line. Data yang telah terkumpul dianalisis dengan menggunakan empat 
tahapan analisis yang telah dikemukakan oleh Meleong yaitu meliputi tahap pengumpulan data, klasifikasi data, reduksi atau penyaringan data, dan penarikan simpulan. Proses reduksi digunakan untuk meningkatkan validitas atau kredibilitas data kepustakaan dan reliabilitas data. Focus Group Discussion dilakukan terhadap hasil analisis. Seluruh masukan FGD menjadi dasar dilakukannya perbaikan, hingga akhirnya naskah akhir siap untuk dipublikasikan.

\section{HASIL DAN PEMBAHASAN}

\section{Hadits-hadits tentang Harta}

Nabi Muhammad Shallallahu 'alaihi wa sallam bersabda yang artinya : Dari Mutharrif dari ayahnya, ia berkata: Aku mendatangi nabi dan beliau tengah membaca: "Bermegah-megahan telah melalaikanmu. (At Takaatsur: 1), beliau bersabda: "Anak cucu Adam berkata: Hartaku, hartaku. Beliau meneruskan: Hartamu wahai anak cucu Adam tidak lain adalah Apa yang kau makan lalu kau habiskan, Apa yang kau kenakan lalu kau usangkan atau Apa yang kau sedekahkan lalu kau habiskan." [HR. Muslim]

Artinya: Sesungguhnya setiap umat memiliki ujian, dan ujian umatku adalah harta.

Artinya: Sesungguhnya orang-orang yang banyak harta adalah orang-orang yang sedikit (kebaikannya) pada hari kiamat, kecuali orang yang diberi harta oleh Allâh, lalu dia memberi kepada orang yang di sebelah kanannya, kirinya, depannya dan belakangnya. Dia melakukan kebaikan pada hartanya. Artinya:

Dari Abu Hurairah Radhiyallahu anhu, dari Rasulullah Shallallahu 'alaihi wa sallam, beliau bersabda, "Jika salah seorang dari kalian melihat orang yang diberi kelebihan harta dan bentuk tubuh, hendaklah dia melihat orang berada di bawahnya. Artinya: Barangsiapa yang melihat orang yang diberi kelebihan bentuk tubuh dan rizqi, maka hendaklah dia melihat orang yang di bawahnya yaitu orang yang diunggulinya, karena hal itu lebih pantas agar dia tidak meremehkan nikmat Allâh yang dianugerahkan padanya.

\section{Konsep Harta Dalam Manajemen Islam}

Kata harta disebut dengan al-māl, yang menurut bahasa berarti condong, cenderung, atau miring. Dari definisi ini bisa dipahami bahwa harta bisa membuat manusia condong atau cenderung hatinya untuk memiliki harta, dan terkadang miring rasionya ketika sudah berhadapan dengan harta. Ada yang berpendapat dari kata kerja māla-yamūlumaulan yang berarti mengumpulkan, memiliki dan mempunyai. Definisi ini memberikan pengertian, sesuatu dimaknai harta bila dapat dikumpulkan untuk dimiliki baik untuk kepentingan individu, keluarga maupun kelompok. Al-mal juga di artikan sebagai segala sesuatu yang menyenangkan manusia dan mereka pelihara, baik dalam bentuk materi, maupun manfaat. Harta adalah benda yang dapat dimiliki, dikuasai, diusahakan, dan dialihkan, baik benda berwujud maupun tidak berwujud, baik yang terdaftar maupun yang tidak terdaftar, baik benda bergerak maupun benda yang tidak bergerak dan hak yang memiliki nilai ekonomis. Menurut al-Syathibi, harta adalah materi yang dapat dikuasai dan memberikan nilai manfaat. Dan Imam Syafi'i menjelaskan, bahwa harta adalah materi yang berharga dan dapat dijadikan sebagai alat tukar di dalam kegiatan jualbeli.

Dalam sebuah riwayat dikatakan: Artinya: Dari Mutharrif dari ayahnya, ia berkata: Aku mendatangi nabi dan beliau tengah membaca: "Bermegah-megahan telah melalaikanmu. (At Takaatsur: 1), beliau bersabda: "Anak cucu Adam berkata: Hartaku, hartaku. Beliau meneruskan: Hartamu wahai anak cucu Adam tidak lain adalah Apa yang kau makan lalu kau habiskan, Apa yang kau kenakan lalu kau usangkan atau Apa yang kau sedekahkan lalu kau habiskan." [HR. Muslim]

Secara terminologi ada dua definisi yang dikemukakan oleh para ulama. 
Pertama: Ulama hanafiyah mendefinisikan al-Mal sebagai segala yang diminati manusia dan dapat dihadirkan ketika diperlukan, atau segala sesuatu yang dapat dimiliki, disimpan, dan dimanfaatkan. bersifat materi. Adapun manfaat termasuk ke dalam pengertian milik. Kedua, menurut jumhur ulama harta itu tidak saja bersifat materi melainkan juga termasuk manfaat dari suatu benda.

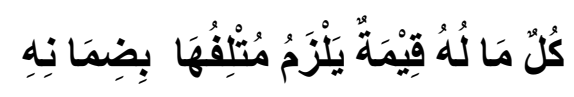

Artinya: Segala sesuatu yang mempunyai nilai dan dikenai ganti rugi bagi yang merusak atau melenyapkannya. Segala sesuatu yang dimanfaatkan pada sesuatu yang legal menurut hukum syara' (hukum Islam) seperti jual beli, pinjaman, konsumsi dan hibah atau pemberian. Harta adalah segala sesuatu yang dapat diambil, disimpan dan dapat dimanfaatkan. Sesuatu yang layak dimiliki menurut syarat serta dapat dimanfaatkan, disimpan/dikuasai dan bersifat konkret.

Berdasarkan definisi ulama Hanafiyah dapat dipahami bahwa yang termasuk harta adalah sesuatu yang dapat dikuasai, dipelihara dan dimanfaatkan. Dengan demikian sesuatu yang tidak disimpan dan tidak dapat dimanfaatkan tidak masuk kategori harta. Sedangkan definisi jumhur ulama lebih terfokus bahwa harta adalah segala sesuatu yang bernilai, yang diutamakan adalah manfaatnya bukan zatnya (benda). Definisi kalangan jumhur ulama tersebut, lebih luas cakupannya, sehingga segala sesuatu yang dimiliki manusia yang memiliki nilai dan manfaat, misalnya tanah, uang, kendaraan, rumah, perhiasan, termasuk juga pakaian, perabotan rumah tangga, hasil perkebunan, hasil karya cipta dan lain-lain, termasuk kategori harta.

Yusuf Qardhawi mengemukakan bahwa yang dimaksud dengan harta (alamwaal) merupakan bentuk jamak dari kata maal, dan maal bagi orang Arab, yang dengan bahasanya al-Qur'an diturunkan, adalah segala sesuatu yang diinginkan sekali oleh manusia untuk menyimpan dan memilikinya. Atas dasar ini, maka segala yang disimpan dan dimiliki manusia termasuk kategori harta.

Lebih spesifik lagi bahwa apapun yang digunakan oleh manusia dalam kehidupan di dunia, merupakan harta baik berupa uang, tanah, kendaraan, rumah, perabotan rumah tangga, perhiasan, hasil perkebunan, hasil perikanan, pakaian dan lain-lain.

\section{Manajemen Harta sebagai Amanah/ Titipan}

Pemilik mutlak harta adalah Allah SWT, oleh karena itu harus dikelola sebagaimana kita mengelola harta titipan. Dari Zubair bin Awam ia berkata, Rasulullah SAW bersabda: "Negara adalah milik Allah, hamba (semua manusia) juga milik Allah di mana saja engkau mendapatkan kebaikan maka tegakanlah (bermukimlah)" (Ahmad, 1998:152)

Hadīs ini memberikan pengertian bahwa negara di mana pun adalah milik Allah, oleh karena itu manusia bisa tinggal di manapun yang ia suka, tentu saja dengan aturan-aturan yang berlaku, orang seharusnya boleh memilih kewarganegaraan, bekerja ke luar negeri untuk mencari penghasilan dan lain sebagainya, begitu pula hamba atau manusia milik Allah, tidak ada perbedaan derajat di antara mereka kecuali taqwa.

Sebagaimana dijelaskan di atas, bahwa kepemilikan oleh manusia hanya bersifat relatif, sebatas melaksanakan amanah Allah yang dipercayakan kepadanya untuk mengelola dan memanfaatkannya pada hal-hal yang baik. Kepemilikan pribadi, baik atas barangbarang konsumsi ataupun barang-barang modal, sangat dihormati walaupun hakikatnya tidak mutlak, dan pemanfaatannya tidak boleh bertentangan dengan kepentingan orang lain dan dengan ajaran Islam.

\section{Manajemen Harta untuk Ibadah}

Kedudukan harta dalam Islam mempunyai peran sangat penting, oleh karena itu harus dikelola (manajemen) 
agar dapat dijadikan sebagai sarana untuk beribadah. Salat, zakat, haji dan jihad semuanya membutuhkan harta sehingga seorang muslim seharusnya memiliki harta, agar dapat melaksakan ibadah secara sempurna. Dalam sebuah Hadīs beliau bersabda:

$$
\text { نعم المال اصا لح للمرء الصالح }
$$

Sebaik-baik harta yang baik adalah harta yang dimiliki oleh hamba yang baik. (Ahmad, 1998: 1186). Dalam Hadīs ini Rasul SAW menjelaskan bahwa harta tidak langsung mempunyai manfaat dan madharat, harta ibarat sebilah pisau. Oleh karena itu, harta harus dikelola dengan baik, karena ia akan bermanfaat jika yang memegangnya adalah koki untuk memasak masakan. Akan tetapi jika pisau dipegang oleh orang jahat, pisau akan menjadi alat untuk menakut-nakuti, melukai, bahkan membunuh manusia.

\section{Manajemen Perolehan dan Penguasaan Harta}

Untuk memperoleh harta harus direncanakan dengan baik. Banyak sekali anjuran untuk bekerja dalam banyak riwayat Hadīs Rasulullah SAW. Seperti Hadīs yang diriwayatkan dari Sahabat Abu Hurairah dan Rafi ibn Khadīj.

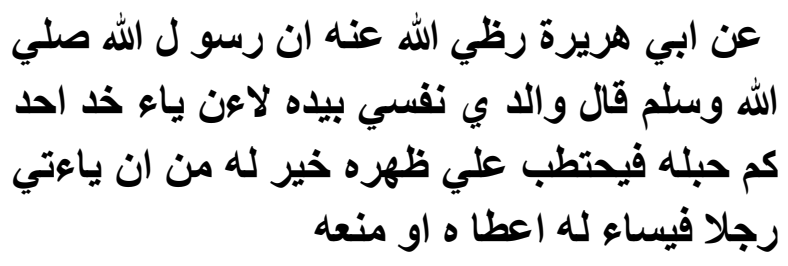

Artinya: Dari Abu Hurairah radliallahu 'anhu bahwa Rasulullah SAW bersabda: "Demi Dzat yang jiwaku berada di tanganNya, sungguh seorang dari kalian yang mengambil talinya lalu dia mencari kayu bakar dan dibawa dengan punggungnya lebih baik baginya daripada dia mendatangi seseorang lalu meminta kepadanya, baik orang itu memberi atau menolak". (Bukhari, 2002 : 357)

\section{عنرا فع بن خليج قال قيل يارسول الله اي الكسب

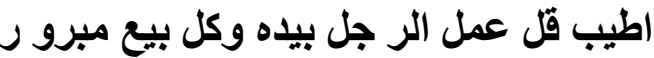

Artinya: Dari Rafi bin Khadij berkata Rasulullah ditanya, wahai Rasulullah pekerjaan apa yang paling baik? Beliau menjawab: Usaha seseorang dengan tangannya sendiri dan jual beli yang baik.(Ahmad, 1998: 1244)

Ḥadīs tersebut menganjurkan manusia agar berusaha memperoleh harta dengan bekerja, bahkan Rasulullah memberikan apresiasi kepada orang yang giat dalam bekerja sebagai orang yang cintai oleh Allah, dan ia bagaikan orang yang berjuang di jalan Allah. Sebenarnya segala harta yang ada di bumi dan di langit adalah milik Allah, maka selama harta tersebut belum dikuasai oleh manusia, harta tersebut boleh dimiliki dan dikelola, sebagaimana sabda Nabi SAW.

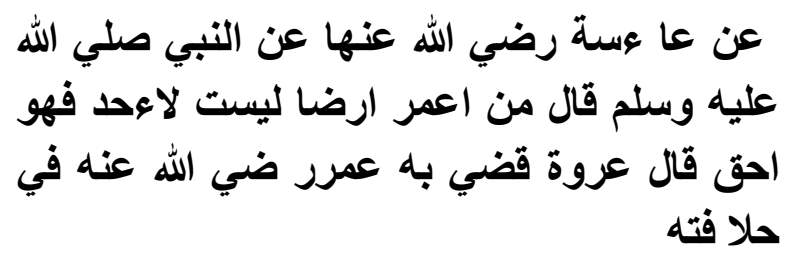

Artinya: Dari Aisyah r.a dari Nabi SAW bersabda: barang siapa yang memakmurkan (menghidupkan) sebidang tanah yang tidak dimiliki seseorang, maka tanah tersebut adalah menjadi hak miliknya. Urwah berkata Umar menetapkan demikian pada era kekhalifahannya. (Bukhari, 2002: 562)

Larangan dan ancaman dari penghasilan yang haram. Baik haram dzatnya maupun haram prosesnya. Dalam sebuah hadits yang diriwayatkan oleh Imam Abu Daud Dari Al-Qasim bin Mukhaimirah radhiyallahu 'anhu, Rasulullah bersabda: جَهَنَ

Artinya: "Barangsiapa mendapatkan harta dengan cara yang berdosa lalu dengannya ia menyambung silaturrahmi atau bersedekah dengannya atau menginfakkannya di jalan Allah, ia lakukan itu semuanya maka ia akan dilemparkan 
dengan sebab itu ke neraka jahannam." (HR. Abu Dawud dalam kitab Al-Marasiil).

Bagi siapa saja yang diberi amanah harta di dunia, maka di akhirat akan dimintai pertanggungjawaban, sebagaimana Rasulullah bersabda:

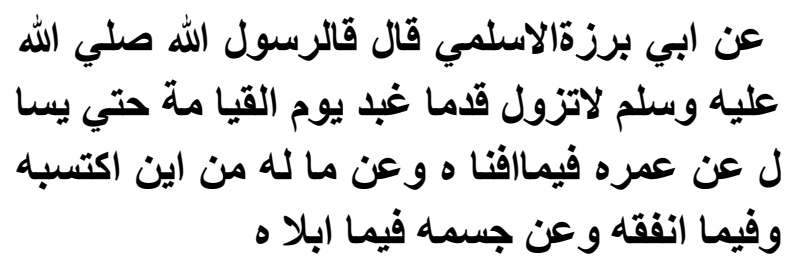

Artinya: Dari Abu Barzah Al-Aslami berkata: Rasulullah SAW bersabda:"Pada hari kiamat kelak seorang hamba tidak akan melangkahkan kakinya kecuali akan ditanya tentang empat perkara; tentang umurnya untuk apa ia habiskan, tentang ilmunya sejauh mana ia mengamālkannya, tentang hartanya darimana ia mendapatkannya dan untuk apa ia pergunakan, serta tentang semua anggota tubuhnya apa yang ia perbuat dengannya."(Tirmiżi, Jilid 2: 882)

Dari Hadīs ini mengingatkan kepada manusia bahwa harta merupakan amanah yang harus hati-hati dalam mencarinya dan harus benar dalam menggunakannya, karena di hari kiamat akan ada pertanggung jawaban dalam mengelola harta. Oleh karena itu, ada empat kelompok manusia dalam mengelola hartanya, pertama, kelompok yang akan selamat, yaitu mereka yang mendapatkan harta dengan cara yang halal dan menggunakannya dengan cara yang halal, kedua, mereka mengumpulkan harta dengan cara yang halal namun digunakan untuk sesuatu yang haram, ketiga, adalah mereka yang mengumpulkan harta dengan cara yang haram kemudian menggunakannya untuk yang halal, demikian pula harta digunakan untuk sesuatu yang halal namun disertai riya', keempat, adalah mereka yang mengumpulkan harta dari jalan haram dan menggunakannya untuk sesuatu yang haram.

\section{Manajemen Pengelolaan Harta}

Islam menganjurkan agar seorang muslim gemar memberi walau sekecil apapun, karena dengan bersedekah ibarat sedang berinvestasi yang akan selalu bertambah keuntungannya, sebagaimana Nabi SAW bersabda:

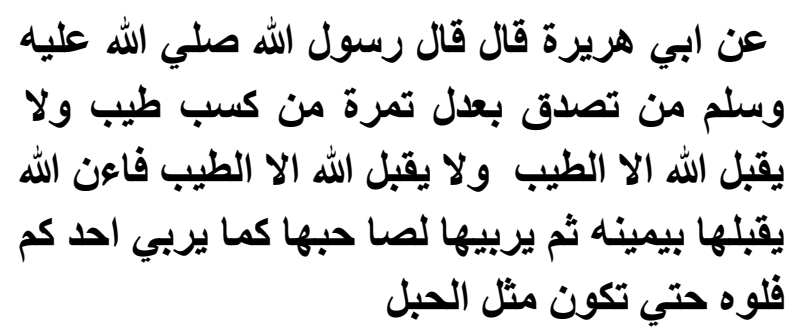

Artinya: Dari Abu Hurairah r.a, ia berkata : "Rasūlullah SAW bersabda: "Siapa yang bersedekah dengan sebiji korma yang berasal dari usahanya yang halal lagi baik (Allah tidak menerima kecuali dari yang halal lagi baik), maka sesungguhnya Allah menerima sedekah tersebut dengan tangan kanan-Nya kemudian Allah menjaga dan memeliharnya untuk pemiliknya seperti seseorang di antara kalian yang menjaga dan memelihara anak kudanya. Hingga sedekah tersebut menjadi sebesar gunung." (Bukhari, 2002: 342)

Salah satu karakteristik ekonomi Islam mengenai harta terutama dalam hal pemanfaatan atau distribusi yang tidak terdapat dalam ekonomi kapitalis maupun sosialis adalah zakat. Sistem perekonomian di luar Islam tidak mengenal tuntutan Allah kepada pemilik harta, agar menyisihkan sebagian harta tertentu sebagai pembersih jiwa dari sifat kikir, dengki, dendam dan sifat buruk lainnya. "Bahwa pada setiap harta seseorang itu ada hak (orang lain) selain zakat". (HR. al- Tirmidzi).

Dari Qotadah, dari Muthorrif, dari ayahnya, ia berkata, "Aku pernah mendatangi Nabi shallallahu 'alaihi wa

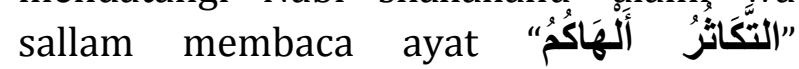
(sungguh berbangga-bangga telah melalaikan kalian dari ketaatan), lantas beliau bersabda: 


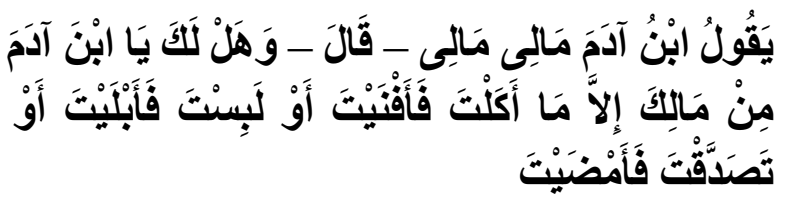

Artinya: "Manusia berkata, "Hartakuhartaku." Beliau bersabda, "Wahai manusia, apakah benar engkau memiliki harta? Bukankah yang engkau makan akan lenyap begitu saja? Bukankah pakaian yang engkau kenakan juga akan usang? Bukankah yang engkau sedekahkan akan berlalu begitu saja?" (HR. Muslim no. 2958)

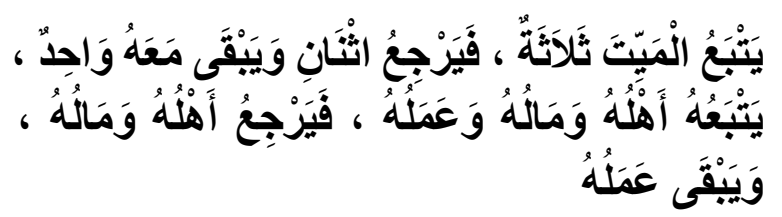

Artinya: "Yang akan mengiringi mayit (hingga ke kubur) ada tiga. Yang dua akan kembali, sedangkan yang satu akan menemaninya. Yang mengiringinya tadi adalah keluarga, harta dan amalnya. Keluarga dan hartanya akan kembali. Sedangkan yang tetap menemani hanyalah amalnya." (HR. Bukhari no. 6514 dan Muslim no. 2960)

Dari Anas bin Malik, Rasulullah shallallahu 'alaihi wa sallam bersabda:

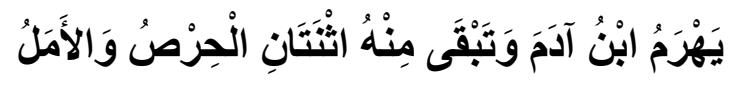

Artinya: "Jika manusia berada di usia senja, ada dua hal yang tersisa baginya: sifat tamak dan banyak angan-angan." (HR. Ahmad, 3: 115. Syaikh Syu'aib Al Arnauth mengatakan bahwa sanad hadits ini shahih sesuai syarat Bukhari-Muslim)

Al Hafizh Ibnu 'Asakir dalam Tarikh Dimasyq menyebutkan biografi Al Ahnaf bin Qois-nama yang biasa kita kenal adalah Adh Dhohak, bahwasanya beliau melihat dirham di genggaman tangan seseorang. Lantas Al Ahnaf bertanya, "Dirham ini milik siapa?" "Milik saya", jawabnya. Al Ahnaf berkata, "Harta tersebut jadi milikmu jika engkau menginfakkannya untuk mengharap pahala atau dalam rangka bersyukur.

\section{Manajemen Harta sebagai Sebuah Ujian}

Harta itu adalah ujian, padahal manusia sangat menyukainya. Oleh karena itu, banyak orang yang gagal dalam menghadapi ujian besar ini. Sedikit sekali orang yang bisa bersyukur kepada Allâh SWT atas limpahan nikmatNya yang tidak terhitung banyak dan nilainya. Setiap umat diuji dengan cobaan yang sesuai dengan keadaan mereka. Nabi Muhammad Shallallahu 'alaihi wa sallam bersabda:

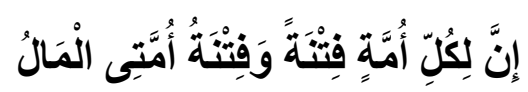

Artinya: Sesungguhnya setiap umat memiliki ujian, dan ujian umatku adalah harta. Setiap umat memiliki ujian, maksudnya kesesatan dan kemaksiatan. Ujian umat ini adalah harta, maksudnya harta menyebabkan kelalaian. Karena harta bisa melalaikan fikiran dari ketaatan dan bisa menyebabkan lupa akhirat. Oleh karena itu, ujian dengan harta akan menampakkan jati diri umat ini, akan menguji kesungguhannya dalam berpegang teguh dengan syari'at, mempertahankan kesucian jiwanya serta akan menguji tekadnya untuk tetap berpegang dengan manhaj yang haq. Nabi Muhammad Shallallahu 'alaihi wa sallam bersabda:

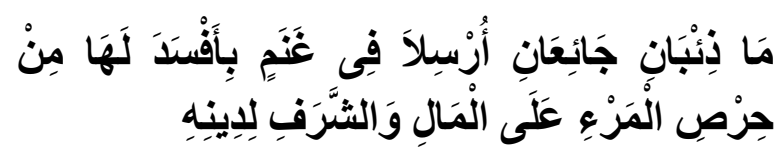

Artinya: Kerusakan pada sekawanan kambing akibat dua srigala lapar yang dilepaskan padanya tidak lebih parah dibandingkan kerusakan pada agama seseorang akibat kerakusannya terhadap harta dan kemuliaan.

Kerusakan yang ditimbulkan oleh harta yaitu ia semacam kekuatan yang mampu menggerakkan syahwat dan menyeretnya untuk bersenang-senang dengan hal-hal mubah, sehingga bersenang-senang itu menjadi kebiasaannya. Bisa jadi, kesenangannya terhadap harta semakin bertambah besar sementara terkadang dia tidak mampu mencari yang halal, akhirnya terjerumus 
dalam perkara syubahat ditambah lagi itu melalaikan dari dzikrullâh. Dan tidak ada seorangpun yang lepas dari hal ini. Nabi Shallallahu 'alaihi wa sallam bersabda:

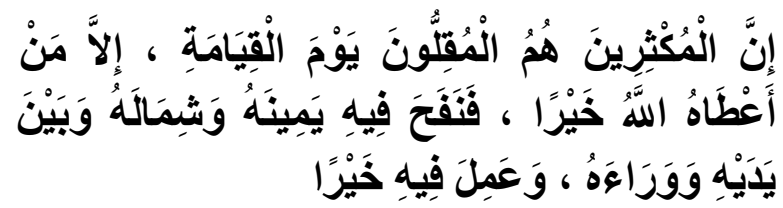

Artinya: Sesungguhnya orang-orang yang banyak harta adalah orang-orang yang sedikit (kebaikannya) pada hari kiamat, kecuali orang yang diberi harta oleh Allâh, lalu dia memberi kepada orang yang disebelah kanannya, kirinya, depannya dan belakangnya. Dia melakukan kebaikan pada hartanya.

Dalam riwayat lain dijelaskan bahwa:

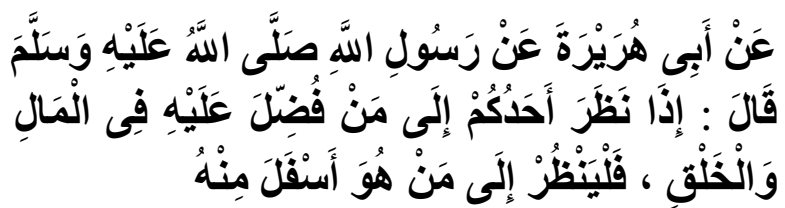

Artinya: Dari Abu Hurairah Radhiyallahu anhu, dari Rasulullah Shallallahu 'alaihi wa sallam, beliau bersabda, "Jika salah seorang dari kalian melihat orang yang diberi kelebihan harta dan bentuk tubuh, hendaklah dia melihat orang berada di bawahnya.

Dalam Sunan Tirmidzi dibawakan dengan lafazh:

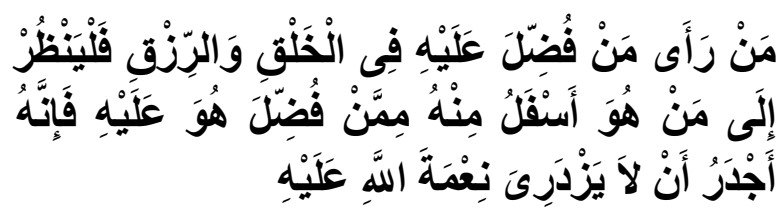

Artinya: Barangsiapa yang melihat orang yang diberi kelebihan bentuk tubuh dan rizqi, maka hendaklah dia melihat orang yang di bawahnya yaitu orang yang diunggulinya, karena hal itu lebih pantas agar dia tidak meremehkan nikmat Allâh yang dianugerahkan padanya.

Ada ulama yang mengatakan bahwa dalam hadits ini terdapat obat dari penyakit. Karena jika seseorang melihat orang yang statusnya lebih tinggi (dalam masalah harta dan bentuk tubuh), maka akan sangat berpotensi menimbulkan hasad pada dirinya, dan obatnya adalah melihat orang yang lebih rendah darinya, sehingga bisa mendorong untuk bersyukur.

\section{Manajemen Harta Agar Tidak Diperbudak Harta}

Maka celaka, celaka orang yang menyembah harta.

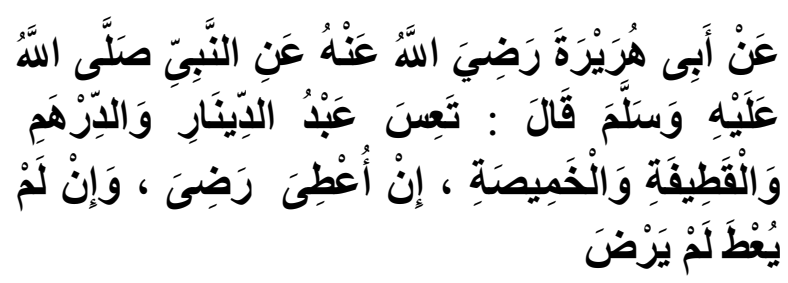

Artinya: Dari Abu Hurairah Radhiyallahu anhu, dari Nabi Shallallahu 'alaihi wa sallam, beliau bersabda, "Celakalah hamba (orang yang diperbudak) dinar, dirham, beludru dan kain bergambar. Jika dia diberi dia ridha, jika tidak diberi dia tidak ridha.

Maka selayaknya, seorang hamba tidak membiarkan dirinya diperbudak harta dalam kehidupannya, selalu berangan-angan dan bermimpi untuk mendapatkannya, mencintai dan membenci karenanya, membela dan memusuhi hanya demi harta. Karena hal itu hanya akan membawa kepada kehancurannya. Oleh karena itu ada larangan sifat kikir terhadap harta termasuk untuk keluarga sekalipun.

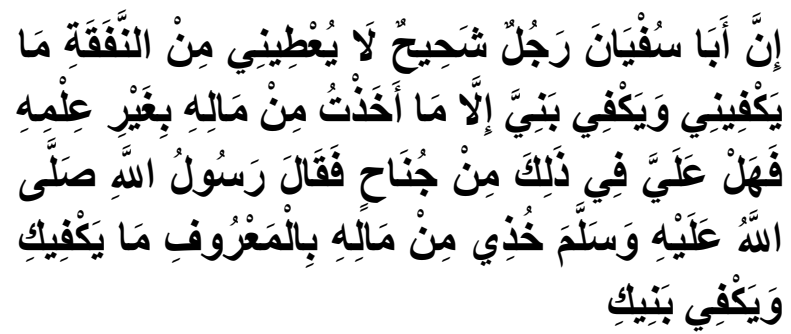

Artinya: Dari 'A 'isyah yang berkata: Hindun binti Utbah istri Abi Sufyan menghadap Rasul SAW, berkata: Wahai Rasul! Sesungguhnya Abu Sufyan itu seorang lakilaki yang sangat kikir. Dia tidak memberi nafaqah padaku dan pada anakku yang mencukupi, kecuali apa yang kau ambil dari hartanya tanpa sepengetahun dia. Apakah 
aku memikul dosa atas perbuatanku itu? Rasil SAW bersabda: ambilah dari hartanya secara ma'ruf apa yang mencukupi kebutuanmu dan menuckupi kebutuhan anakmu. Hr. Muslim (206-261H) Manajemen Harta dalam Rangka Mensyukurinya

Dalam sebuah riwayat dikatakan:

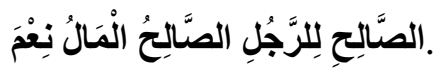

Artinya: "Sebaik-baik harta yang baik adalah yang dimiliki orang yang shalih." (HR. Ahmad di dalam Al-Musnad IV/202, no. 17835 dengan sanad yang hasan). Harta yang baik lagi halal yang ada di tangan orang muslim yang sholih memiliki banyak manfaat dan keistimewaan bagi dirinya, keluarganya maupun orang lain, baik itu menyangkut urusan dunia maupun agama. Ini tentu saja orang yang pintar mengelolanya adalah hamba Allah yang sholih yang mengerti kedua maslahat ini.

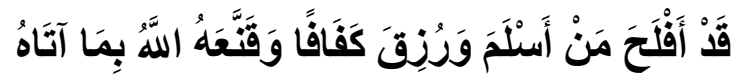

Artinya: "Sungguh sangat beruntung orang yang telah masuk Islam, diberikan rizki yang cukup dan Allah menjadikannya merasa puas dengan apa yang diberikan kepadanya." (HR. Muslim no. 1054)

Terkadang di antara manusia ada yang tertipu dengan harta yang dimilikinya, seakan-akan harta tersebut akan mengekalkannya di dunia, padahal tidak demikian. Perhatikanlah hadits berikut ini dimana Nabi saw menjelaskan tentang mana yang sebenarnya harta kita, sehingga kita tidak tertipu oleh harta tersebut.

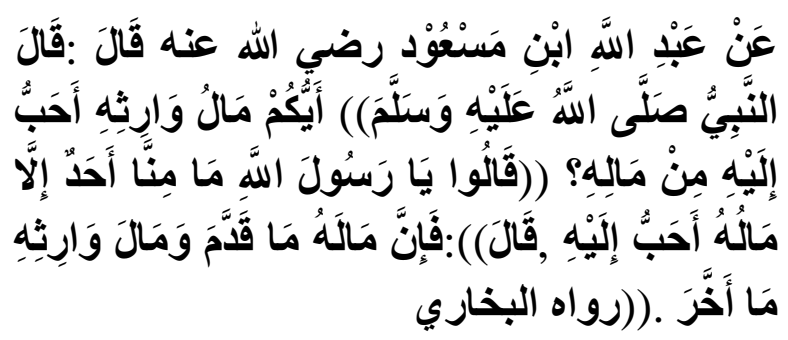

Artinya: Dari Abdullah bin Mas'ud rd ia berkata, Nabi saw bersabda: "Siapakah diantara kalian yang harta ahli warisnya lebih ia cintai daripada hartanya sendiri?" Mereka (para shahabat) menjawab, Tidak ada diantara kami kecuali hartanya lebih ia cintai, Beliau saw bersabda: "Sungguh hartanya adalah apa yang telah ia infakkan dan harta ahli warisnya adalah yang ia tinggallakan (tidak diinfakkan)." (HR. Bukhari)

Secara tabiat, manusia pasti mencintai yang namanya harta. Akan tetapi mereka berbeda-beda dalam kadar kecintaan terhadap harta tersebut. Ada diantara mereka yang mencintai harta melebihi cintanya kepada Allah dan rasulNya, bahkan hak Allah dan rasul-Nya diabaikan demi meraup harta tersebut, sehingga hartanya akan membuat dia celaka dan sengsara di dunia lebih-lebih di hari akhirat.

Rasulullah saw dalam hadits yang mulia ini ingin menjelaskan kepada kita bahwa harta yang yang sebenarnya atau harta yang akan memberi manfaat bagi kita di hari akhirat nanti adalah harta yang telah kita keluarkan di jalan Allah baik dengan berinfak, bershadakoh, manyantuni anak yatim dan lain-lain.

\section{Kewajiban Menjaga Harta}

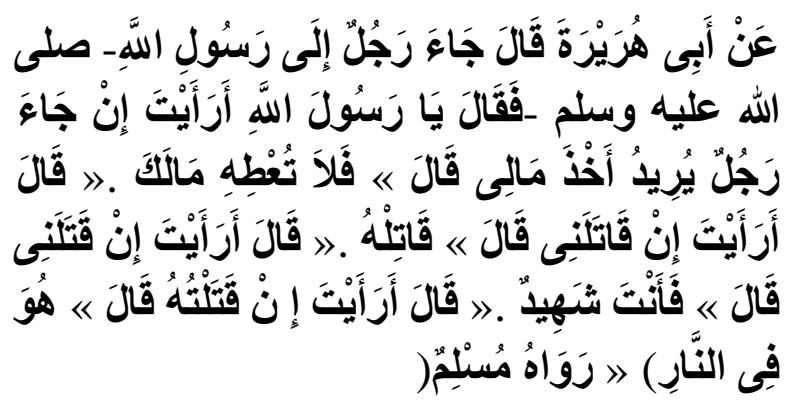

Artinya: Dari Abu Hurairah RA berkata: ada seorang laki-laki menghadap Rasulullah SAW, ia berkata : ya Rasulullah bagaimana pendapat kamu jika ada seorang laki-laki yang ingin merampas hartaku?, Rasulullah menjawab: jangan kau berikan hartamu, ia berkata: bagaimana pendapat kamu jikalau ia ingin membunuhku?, Rasulullah bersabda: bunuhlah dia, ia bekata: bagaimana pendapatmu jika dia telah membunuhku ?, Rasulullah bersabda; kamu mati syahid, ia berkata; bagaimana 
pendapatmu jikalau aku berhasil membunuhnya?, ia masuk neraka). HR Muslim).

\section{KESIMPULAN DAN IMPLIKASI}

Berdasarkan uraian di atas dapat disimpulkan:

1. Harta adalah benda yang dapat dimiliki, dikuasai, diusahakan, dan dialihkan, baik benda berwujud maupun tidak berwujud, baik yang terdaftar maupun yang tidak terdaftar, baik benda bergerak maupun benda yang tidak bergerak dan hak yang memiliki nilai ekonomis.

2. Pemilik mutlak harta adalah Allah SWT, oleh karena itu harus dikelola sebagaimana kita mengelola harta titipan. Bagi siapa saja yang diberi amanah harta di dunia, maka di akhirat akan dimintai pertanggungjawaban. Harta merupakan amanah yang harus hati-hati dalam mencarinya dan harus benar dalam menggunakannya, karena di hari kiamat akan ada pertanggung jawaban dalam mengelola harta.

3. Kedudukan harta dalam Islam mempunyai peran sangat penting, oleh karena itu harus dikelola (manajemen) agar dapat dijadikan sebagai sarana untuk beribadah. Harta dimiliki oleh orang sālih, maka harta akan sangat bermanfaat sebagai wasilah menunaikan ibadah dan kemaslahatan umum. Namun bila harta dimiliki oleh orang jahat harta akan sangat berbahaya, karena bisa merusak sendi-sendi perekonomian dan kemaslahatan masyarakat.

4. Untuk memperoleh harta harus direncanakan dengan baik. Banyak sekali anjuran untuk bekerja. Nabi Muhammad SAW menganjurkan manusia agar berusaha memperoleh harta dengan bekerja, bahkan Rasulullah memberikan apresiasi kepada orang yang giat dalam bekerja sebagai orang yang cintai oleh Allah, dan ia bagaikan orang yang berjuang di jalan Allah.

5. Harta itu adalah ujian, padahal manusia sangat menyukainya. Oleh karena itu, banyak orang yang gagal dalam menghadapi ujian besar ini. Sedikit sekali orang yang bisa bersyukur kepada Allâh SWT atas limpahan nikmatNya yang tidak terhitung banyak dan nilainya.

6. Celakalah orang yang menyembah harta.

\section{DAFTAR PUSTAKA}

Al-Atsari, Abu Isma'il Muslim. "Harta, Sumber Celaka?" Majalah As-Sunnah Edisi 02/Tahun XIV/1431/2010M. On-line:

https://almanhaj.or.id/3537-hartasumber-celaka.html. Accessed: 23 September 2018

Al-Munawiy, Syamsuddin. 2016. Beberapa Kewajiban Berkenaan Dengan Harta. On-line: http://wahdah.or.id/beberapakewajiban-berkenaan-denganharta/ diakses tanggal 7 Oktober 2018

Al-Nabhani, Taqiyuddin. 1995. Membangun Sistem Ekonomi Alternatif, Perspektif Islam (terj), Surabaya: Risalah Gusti

El-Majalis. Syarah Hadits: Harta Anda Yang Sebenarnya. On-line: http://www.elmajalis.com/2014/01 /syarah-hadits-harta-anda-yangsebenarnya.html

Hadi, Firdausia. 2016. Hukum Menjaga Hak Milik Pribadi Bagi Seorang Muslim. on-line:

https://www.kompasiana.com/firda usiahadi/57d7f021589373394b595 c7b/hukum-menjaga-hak-milikpribadi-bagi-seorangmuslim?page=all diakses tanggal 7 Oktober 2018

Hadis tentang Harta. On-line: https://areksumberjati.wordpress.c 
om/2014/12/09/hadits-tentangharta/ acessed: 23 September 2018

Haroen, Nasrun. 2007. Fiqh Muamalah. Jakarta: Gaya Media Pratama

HR. Bukhâri-Muslim

Ma'u, Dahlia Haliah. "Harta Dalam Perspektif Al-Qur'an.” Jurnal Khatulistiwa - Journal Of Islamic Studies, Volume 3 Nomor 1 Maret 2013. Hal 88-89. On-line: https://jurnaliainpontianak.or.id/in dex.php/khatulistiwa/.../173

Acessed: 20 September 2018

Masrur, Muhamad. 2017. "Konsep Harta dalam Al-Qur'ān dan Hadīs." Jurnal Hukum Islam, Vol. 15, No. 1, Juni 2017 hal 96 On-line: ejournal.iainpekalongan.ac.id/index.p hp/jhi/article/view/.../1186, Acessed 24 September 2018

Meleong, Lexy J., 1995, Metode Penelitian Kualitatif, Bandung: PT Remaja Rosdakarya

Mujieb, M. Abdul (et al), 1994. Kamus Istilah Fiqih. Jakarta: PT. Pustaka Firdaus

Palupi, Wening Purbatin. 2013. "Harta Dalam Islam (Peran Harta Dalam Pengembangan Aktivitas Bisnis Islami)" At-Tahdzib Vol.1 Nomor 2 Tahun 2013. Hal 154-155 on-line: ejournal.kopertais4.or.id/matarama n/index.php/tahdzib/.../970 acessed: 24 September 2018
Qardhawi, Yusuf. 1991. Fiqh Zakat, Beirut: Muassasah Risalah

Rahman, Afzalur. Doktrin Ekonomi Islam (terj) jilid 1. Yogyakarta: Dana Bakti Wakaf, 1995, 6

Rifai, Veitsal \& Andi Buchari, 2009. Islamic Economics. Jakarta: PT. Bumi Aksara

Salam, Ibnu Abdi. Tt. Qowaid al-Ahkam fi Masholihu al-Anam, Beirut: Darul Jail, jilid I.

Sarah, Siti. Harta Menurut Al-Qur'an dan Hadits.

On-line:

http://sarahleeairashii.blogspot.co m/2014/03/ayat-dan-haditsmengenai-harta.html Acessed: 21 September 2018

Subhan ZA, Moh. Ah. 2016. Konsep Harta Perspektif Ekonomi Islam. Akademika, Volume 10, Nomor 2, Desember 2016. Hlm 264 On-line: journalfai.unisla.ac.id/index.php/AK ADEMIKA/article/.../23/20/

Acessed: 21 September 2018

Suhendi, Hendi. 2002. Fiqh Muamalah. Jakarta: Raja Grafindi Persada.

Tiga Macam Harta Manusia. https://mromi.wordpress.com/201 2/07/26/tiga-macam-hartamanusia/ Acessed: 21 September 2018

Tuasikal, Muhammad Abduh. Saling Berbangga dengan Harta. https://rumaysho.com/2138-salingberbangga-dengan-harta.html 